\title{
ENGENHARIA EPISTÊMICA: ENTREVISTA COM MURILO SEABRA,
} PARTE 2

\author{
Murilo Seabra ${ }^{1}$ \\ https://orcid.org/0000-0003-2055-4265 \\ Lúcio Verçoza ${ }^{2}$ \\ https://orcid.org/0000-0001-5892-938X
}

\begin{abstract}
RESUMO
Para entender a trajetória e as ideias de Murilo Seabra, é preciso retomar o polêmico "Discurso aos Estudantes sobre a Pesquisa em Filosofia", de Oswaldo Porchat Pereira, professor recentemente falecido (2017) da Universidade de São Paulo, Brasil. A tese central de Porchat é que existe uma diferença incontornável entre sentar para escrever um trabalho filosófico e sentar para escrever um trabalho de história da filosofia. Na presente entrevista, realizada por email entre os dias 23 de Setembro e 22 de Dezembro de 2018, Murilo Seabra conta um pouco de suas experiências como estudante, defende a radicalização do discurso de Porchat, fala da importância de se combater o racismo e o sexismo na academia, discute a ascensão do pós-estruturalismo e a derrocada do marxismo durante a Guerra Fria e analisa o papel da filosofia na atual conjuntura política brasileira. Apesar de ter sido realizada antes da posse do novo presidente Jair Bolsonaro, a entrevista mostra uma presciência notável. "Já tínhamos uma filosofia sem o Brasil", escreveu Murilo Seabra. "Agora corremos o risco de ter um Brasil sem filosofia". A pedido dos editores, alguns momentos agressivos foram suprimidos e as críticas ao presidente Jair Bolsonaro foram moderadas. Por conta de sua extensão, a entrevista foi dividida em duas partes.
\end{abstract}

Palavras-chave: engenharia epistêmica; preferências implícitas; Guerra Fria; filosofia no Brasil.

Palabras clave: reciclaje, plan de negocios, microorganismos, ambiente, residuos orgánicos.

Ingenieria Epistemica: Entrevista con Murilo Seabra, Parte 2.

RESUMEN

Para entender la trayectoria de Murilo Seabras e ideas, necesitamos retomar el polémico "Discurso a los estudiantes sobre la investigación en filosofía" de Oswaldo Porchat Pereira, un profesor recientemente fallecido (2017) de la Universidade de São Paulo, Brasil. La tesis central de Porchat es que existe una diferencia incontrolable entre sentarse para escribir un trabajo filosófico y sentarse a escribir un trabajo sobre historia de la filosofía. En esta entrevista, conducida vía email entre el 23 y 28 de septiembre de 2018, Murilo Seabra habló acerca de su experiencia como estudiante, defendiendo la radicalización del discurso de Porchat, habla de la importancia de combatir el racismo y sexismo en la academia, discute el aumento del posestructuralismo y el colapso del Marxismo durante la guerra fría, analiza el rol de la filosofía en la actual conjetura política brasileña. A pesar de haber sido realizada antes del nombramiento de Jair Bolsonaro, la entrevista muestra una presencia notable "ya teníamos una filosofía sin Brasil" escribió Murilo Seabra, "ahora corremos el riesgo de tener un Brasil sin filosofía”. A pedido de los editores, algunas frases agresivas fueron eliminados y las críticas al presidente Bolsonaro fueron moderadas. Debido a la extensión, la entrevista fue dividida y publicada en dos partes.

Palabras Clave: Ingeniería Epistemica; preferencias implícitas; Guerra Fría; Filosofia en Brasil.

Epistemic engineering: Interview with Murilo Seabra, part 2

\section{RESUMO}

To understand Murilo Seabra's trajectory and ideas, we need to review those of Oswaldo Porchat Pereira, a recently deceased professor (2017) from the University of São Paulo, Brazil, as found in Porchat's polemic "Student Discourse on Philosophy Research." Porchat's central thesis is that there is an inescapable difference between sitting down to write a philosophical work and sitting down to write a work on the history of philosophy. In this interview, conducted by e-mail between September 23 and December 22, 2018, MuriloSeabra talks about his experiences as a student, defends the radicalization of Porchat's discourse, points out the importance of fighting racism and sexism in academia, discusses the rise of poststructuralism and the collapse of Marxism during the Cold War, and analyzes the role of philosophy in the current Brazilian political situation. Although it was carried out before the inauguration of the new head of state, Jair Bolsonaro, the interview shows remarkable foresight. "We already had a philosophy without Brazil," wrote MuriloSeabra. "Now we run the risk of having a Brazil without philosophy." At the request

${ }^{1}$ Doutor em filosofia pela La Trobe University, Melbourne, Austrália. Correo electrónico: murilorseabra@gmail.com

${ }^{2}$ Doutor em sociologia pela Universidade Federal de São Carlos (UFSCar) e professor da Universidade Federal de Alagoas (UFAL), Brasil. Correo electrónico: luciovercoza@yahoo.com.br 
of the editors, some aggressive moments were suppressed and criticisms of President Jair Bolsonaro were moderated. Due to its length, the interview was divided into two parts.

Keywords: epistemic engineering; implicit preferences; Cold War; philosophy in Brazil.

Na sociologia existem muitos trabalhos nos quais os autores não se reconhecem em seus textos. Parece que a própria forma da escrita acadêmica, como você bem apresenta em seu livro, é algo que cria obstáculos para que a energia se transmute em texto. os resultados, muitas vezes, são escritos cheios de casamatas de defesa e com a energia criadora reprimida. Depois gostaria de retomar o tema da conjuntura e da ação política. Mas antes, gostaria que você falasse um pouco sobre sua mais recente pesquisa. Como é que você chegou no projeto de pesquisa empírica sobre as mentalidades nos departamentos de filosofia brasileiros?

O que eu fiz foi muito simples. Eu desenvolvi dois questionários que foram aplicados para pouco mais de 90 professores e pós-graduandos de filosofia. Os questionários continham três textos que os respondentes deveriam avaliar de acordo com uma série de critérios, como originalidade, coerência e profundidade. Os respondentes também tinham que informar, na primeira página, as coisas usuais, isto é, gênero, idade, área de interesse, se tinham alguma formação além da formação em filosofia e assim por diante. É o procedimento padrão. Os dois questionários eram idênticos em quase tudo. Os textos do primeiro questionário eram idênticos aos textos do segundo. E as perguntas também, claro. Tudo idêntico, nos mínimos detalhes. A única diferença é que os textos atribuídos a autores latino-americanos num questionário eram atribuídos a autores europeus no outro. E o que os resultados mostraram? Eles mostraram que a nacionalidade do autor afeta, sim, a nossa percepção de qualidade da sua produção teórica. Quando um texto é assinado por um francês, ele é visto como qualitativamente melhor do que quando ele é assinado por um brasileiro. Ele tem até mais chances de ser indicado para publicação. A nacionalidade brasileira tem um efeito deletério. Ela tem um efeito desagregador. O que aconteceu, claro, não foi que todos os respondentes avaliaram o autor francês de maneira mais positiva do que o autor brasileiro. A coisa não é mecânica. É possível, portanto, que haja pessoas nos departamentos de filosofia que não tendem a favorecer os europeus em detrimento dos latino-americanos. Mas elas são a minoria. É possível afirmar com certeza que elas são a minoria.

Mas a coisa não começou com o meu doutorado. A ideia surgiu muito antes, quando eu ainda estava em Brasília. Não lembro exatamente como nem quando. Mas lembro que a ideia dos questionários me veio como um relâmpago. Ela mobilizou todo o meu ser. Ela poderia colocar um fim na controvérsia sobre a filosofia brasileira. Junto com dois ou três autores, incluindo o Porchat, eu achava que os brasileiros eram discriminados pela comunidade acadêmica de filosofia. Eu tinha certeza, na verdade. Só que a comunidade acadêmica achava que os brasileiros não eram excluídos por serem brasileiros, mas por serem autores de baixa qualidade. A seleção era estritamente racional. Então o argumento da qualidade precisava ser enfrentado. Porque ele era sempre levantado para dizer que o Porchat estava errado, que o Cabrera estava exagerando, que o Gonzalo estava delirando. E como enfrentá-lo? Impedindo que ele pudesse ser acionado. E como impedi-lo de ser acionado? Através da conservação da qualidade. Quando você tem dois textos idênticos sendo avaliados de maneira diferente, não dá para dizer que eles estão sendo avaliados de maneira diferente porque um é melhor do que o outro. A qualidade é a mesma.

Acho que vale a pena deixar claro que não era coisa de $1 \%$ contra $99 \%$. O pressuposto de que os departamentos de filosofia brasileiros operavam de maneira estritamente racional não era questionada por ninguém. O discurso do Porchat e o De como fažer filosofia sem ser grego, estar morto ou ser gênio do Gonzalo eram exceções absolutas. E além de serem exceções, eles não tinham nenhuma aceitação. A quantidade de pessoas que acreditam em Deus nos departamentos de filosofia brasileiros é seguramente muito maior do que a quantidade de pessoas que suspeitam de sua racionalidade. Curiosamente, porém, eu ouvi repetidas vezes que a minha pesquisa só estava mostrando o que todo mundo já sabia. Todo mundo? A gente tem que lembrar que a 
comunidade acadêmica brasileira é uma das maiores do planeta. Tem mais gente estudando filosofia alemã no Brasil do que na Alemanha. O que são dois ou três autores no meio desse oceano de comentadores? Não tem sentido dizer que todo mundo já sabia que a produção teórica dos brasileiros era discriminada. A coisa era veementemente e universalmente negada. $\mathrm{E}$ continua a ser veementemente e universalmente negada.

Mas dá para entender o motivo pelo qual os meus críticos vieram com essa coisa de que eu só estava mostrando o que todo mundo já sabia. A afirmação "Todo mundo já sabe disso" tem um efeito deslegitimador. Isso é algo que não dá para negar. Se você está dizendo algo que todo mundo já sabe, então o que você está fazendo realmente não tem nenhum valor. Não é que a sua afirmação $p$ esteja errada. Mas não há razão nenhuma para dizer $p$. Quando você diz $p$ para uma comunidade que já sabe $p$, então você está mostrando que você não está por dentro das coisas. Você está mostrando a sua incompetência. Antes da pesquisa empírica, ninguém concordava com $p$. Aliás, $p$ consistia em um erro crasso. $\mathrm{E}$ dizer $p$ não era apenas cometer um erro intelectual, mas também um erro moral. Além de não saber do que estava falando, quem defendia $p$ também era ressentido. Depois da pesquisa, voilà, de repente todo mundo já sabia que $p$. Primeiro, era errado dizer $p$ porque havia um erro $\operatorname{com} p$. Agora continua sendo um erro dizer $p$, só que não por causa do conteúdo de $p$ e sim por causa do caráter vazio do ato de dizer $p$. Tanto num caso quanto no outro, uma coisa fica muito clara: não se deve dizer $p$. Agora que $p$ veio à tona, é preciso submergir $p$ no silêncio de novo. É enlouquecedor. O seu interlocutor nega que $10+10=20$, você gasta tempo e energia para convencê-lo que $10+10=20$ e ele responde que já sabia que $10+10=20$. Você sempre está errado e ele sempre está certo.

Talvez o meu erro tenha sido pensar que os membros dos departamentos de filosofia responderiam de forma racional aos resultados da minha pesquisa. A verdade é que a maior parte deles só está ali para ter um emprego mesmo. Eles não têm nenhum compromisso sério com o que estão fazendo. O problema não é só da filosofia. Você vai encontrar muito mais pizzaiolos que só estão fazendo pizza para ganhar dinheiro do que pizzaiolos que estão ali trabalhando por paixão. Se você for discutir a consistência da massa, a temperatura do forno e as variedades de queijo com o pizzaiolo que tem paixão pelo que faz, ele vai concordar com você quando você estiver certo e discordar de você quando você estiver errado - e vai explicar porquê. Ele vai escutá-lo com atenção. A conversa será transparente e marcada pela honestidade. Mas se você for discutir com um pizzaiolo que só está ali para ganhar dinheiro, ele vai dizer imediatamente que você está errado, e quando você mostrar que é ele que está errado, ele vai dizer que nunca disse o que acabou de dizer dois minutos atrás. O importante para ele não é conversar e sim vencer a discussão. Ele opera no modo competitivo, não no modo colaborativo. Talvez ele até se sinta ameaçado pela sua abertura ao diálogo. Porque ela o convida a olhar para a própria desonestidade. Então eu achei que uma pesquisa empírica poderia colocar um fim na controvérsia. Ela poderia mostrar de forma contundente que havia, sim, preconceito contra o pensamento subequatorial. Infelizmente, porém, quando você corta a cabeça da hidra, nascem duas cabeças para substituí-la. É como tentar conversar com a Kellyanne Conway. Não adianta. Você apresenta fatos e ela apresenta fatos alternativos. Você leva meses pesquisando, coletando dados, analisando tudo com cuidado, e ela destrói todo o seu trabalho em um segundo com uma idiotice qualquer sem pé nem cabeça. Ele continua sólido e consistente. Ele continua robusto e afiado. Mas sem nenhuma credibilidade, sem nenhuma legitimidade. Por quê? Porque o mundo da filosofia é controlado por pizzaiolos medíocres. Eles dominam a cena. Eles distribuem os predicados intelectuais - e até mesmo os predicados morais! - do jeito que eles querem. É possível que não tenham votado no Bolsonaro. Espero que não tenham votado no Bolsonaro. Mas eles são bolsonarozinhos em sua própria área de atuação.

O primeiro lugar onde apliquei o questionário foi na Universidade Católica de Brasília (UCB). O questionário original, se me lembro bem, tinha dez questões. Uma das questões obviamente não funcionou. Ela não acusou nenhuma preferência pelo autor europeu em detrimento do autor latino-americano. As outras nove questões, porém, tinham funcionado muito bem, algumas 
melhor que as outras. Os estudantes homens também pareciam ter sido mais críticos do que as estudantes mulheres com as autoras mulheres. $\mathrm{O}$ instrumento que tinha sido desenvolvido para detectar preconceito de nacionalidade estava afirmando, de maneira inesperada, que havia também preconceito de gênero. O segundo passo foi aplicar o questionário na UnB. Eu não lembro se a questão que não tinha funcionado foi substituída ou modificada. Mas lembro que os resultados foram impressionantes. Não dava para negar que havia algo importante ali. Mas havia um problema. O questionário tinha sido elaborado e aplicado por estudantes. Eu não tinha nem concluído o mestrado na época. Além do mais, a minha formação não era nem em sociologia nem em psicologia. Eu tinha estudado filosofia, o que significava que, do ponto de vista formal, eu não estava preparado para fazer pesquisas empíricas. Eu não tinha as credenciais adequadas. Os meus amigos, que me ajudaram tanto na elaboração quanto na aplicação do questionário, também não tinham. Então a gente estava com resultados bastante explosivos em mãos, só que resultados que corriam o risco de serem desacreditados porque a gente não tinha as credenciais adequadas.

Os meus amigos me convenceram que era importante fazer uma nova aplicação do questionário. Eles queriam incluir um professor na equipe para dar seriedade à coisa. Foi aí que o projeto começou a desandar. O professor sugeriu fazer uma modificação no questionário que não desceu bem na minha garganta. Eu sou da escola que acredita que não se mexe em time que está ganhando. Os meus amigos, porém, defenderam o professor unanimemente. Ele nunca tinha feito uma pesquisa parecida. Ele não ficou anos quebrando a cabeça com o assunto, nem meses trabalhando no questionário, avaliando cuidadosamente todas as suas nuances, pensando meticulosamente em todos os seus detalhes. Mas ele tinha as credenciais adequadas. Ele certamente sabia do que estava falando. Ele estava certo e eu errado. Eu acabei cedendo e o resultado foi catastrófico. Eu gastei uma fortuna para fazer uma nova aplicação do questionário que não podia mais ser em Brasília, porque ele já tinha sido aplicado na UCB e na UnB - só para ver o navio naufragar. O problema não foi apenas que o instrumento de coleta de dados perdeu sua capacidade de discriminação com a modificação introduzida pelo professor. O problema foi que eu estava sustentando todo o projeto financeiramente sozinho. Eu não tinha apoio institucional. Aliás, a maior parte dos professores que eu tinha contatado havia me tratado com hostilidade. Os meus amigos só contribuíam com opiniões e entusiasmo. Na prática, eu estava empurrando o barco sozinho. Eu apostei as minhas últimas fichas na nova aplicação do questionário, que foi feita em São Paulo, e a coisa não funcionou. Eu não tinha mais forças para continuar nadando contra a maré. Então resolvi jogar tudo na fogueira. Os questionários - e todo o projeto de capturar preconceitos epistêmicos inconscientes, que parecia bastante promissor - viraram cinzas. O único rastro que você vai encontrar dessa experiência está no Metafilosofia, que se alimentou em grande parte dos resultados obtidos na UnB.

Foi só em 2014 que retomei o projeto. Depois de passar um tempo na Alemanha e de viajar pela África, resolvi aceitar uma oferta de bolsa de estudos para fazer doutorado na Austrália. Eu cheguei na Austrália em março de 2014 para estudar o problema da mineração em terras indígenas. Só que as coisas não estavam indo bem. Para mim, estava fora de questão o caráter absolutamente atroz do que a indústria mineradora fazia nas terras indígenas. Mas a literatura acadêmica sobre o assunto é deplorável. Tentando ser imparcial e balanceada, ela distorce completamente as coisas, enfatizando as práticas ecológicas das mineradoras e as práticas antiecológicas dos povos indígenas. É nojento. E o meu orientador queria que eu participasse do circo. Por sorte ou por azar, ele abandonou a universidade no final de 2014. Eu poderia ter continuado com o meu projeto. Só que tinha ainda um outro problema, a Fundação Nacional do Índio (FUNAI). Para você fazer pesquisa de campo em terras indígenas brasileiras, você precisa da autorização da FUNAI, e me disseram, pelos bastidores, que o meu projeto seria barrado. Para piorar as coisas, o meu co-orientador brasileiro, do departamento de antropologia da UnB, não parecia interessado em me ajudar a encontrar uma solução para o problema. Ele até insinuou que eu poderia acabar entrando para o lado do opressor, como frequentemente acontece, 
segundo ele, com quem luta contra a opressão. Foi a gota d'água. Eu resolvi mudar de tema. Foi assim que retomei o projeto de investigar os departamentos de filosofia brasileiros.

Eu achei que as coisas seriam mais fáceis. Pode ser que tenham sido mais difíceis. Eu atraí inimizades de todo lado. É o preço que se paga por lutar contra o preconceito. A historiadora que estuda as imagens do corpo humano no século XIX tem problemas só pelo fato de ser mulher. A historiadora que foca o seu estudo nas imagens do corpo feminino no século XIX tem ainda mais problemas, porque, por causa do seu recorte temático, ela se abre para a acusação de estar misturando militância política à sua pesquisa histórica. As coisas são ainda piores para a historiadora que estuda o preconceito contra as mulheres. Ela já não está mais fazendo história. O que ela está fazendo é pura e simplesmente política. E a historiadora que estuda o preconceito contra as historiadoras? Ela é encarnação do demônio. Ela precisa ser queimada na fogueira. Porque ela está colocando em questão o funcionamento cognitivo dos seus pares. Ela não está apenas transgredindo um ou dois tabus. Ela está levando a coisa até suas últimas consequências. Ela está transgredindo tudo o que há para ser transgredido. É claro que a competência dela vai ser atacada. É claro que a metodologia dela vai ser criticada como inadequada. É claro que seus colegas vão olhar para ela atravessado. É claro que ela vai ser chamada de histérica. É claro que ela não vai ser convidada para conferências, seminários e para grupos de discussão. É claro que ela vai ouvir que, na verdade, é ela a preconceituosa. É claro que se ela não desistir de tudo, continuar lutando e terminar a pesquisa, ela vai acabar escutando que descobriu algo que todo mundo já sabia. Eu não tive problemas com a FUNAI. Mas tive problemas com a academia.

\section{Não imaginava que a recepção fosse essa, pois sua pesquisa toca a ferida com dados empíricos - algo que ainda não havia sido feito. Queria que você falasse mais sobre os dados levantados e sobre os desafios para realização e divulgação desse estudo.}

O que eu descobri, o que eu consegui mostrar, é que, numa escala de 0 a 10, o mesmo texto filosófico receberá em média 0,96 ponto a mais se o autor for francês ao invés de brasileiro. A coisa é preocupante? Sim, é muito preocupante. Especialmente quando a gente lembra que o questionário foi respondido por membros da comunidade filosófica brasileira. Ela discrimina contra si mesma. Na literatura sobre preconceitos inconscientes - ou vieses implícitos, como os pesquisadores de língua inglesa preferem chamá-los -, você encontra uma série de estudos mostrando que temos uma tendência a favorecer o nosso próprio grupo. Mas o que acontece aqui é justamente o contrário. Estamos desfavorecendo o nosso próprio grupo. Houve dois ou três professores estrangeiros respondendo o questionário, não lembro bem quantos, e também não lembro se eles deixaram o favorecimento do autor francês mais forte ou mais ameno. Seja como for, a contribuição deles para o resultado final foi muito pequena. O que a gente tem aqui é claramente a comunidade brasileira operando contra si mesma. Ela tem um pé atrás em relação a si mesma.

A magnitude do efeito pode parecer pequena. O que é 0,96 ponto? Você acha que 0,96 é um valor insignificante? Você sente que é um valor insignificante? É possível que a sua reação contra o 0,96 não seja só intelectual, mas também emocional. É possível, aliás, que ela seja puramente emocional. Você simplesmente não consegue evitar a sensação inamovível, persistente, insistente de que 0,96 não é nada e de que não pode ter nenhum efeito significativo no mundo real. Uma das críticas que recebi recentemente foi justamente que 0,96 não era nada, que eu estava superestimando a magnitude do efeito de 0,96 . Então eu não me surpreenderia se outras pessoas também sentissem que 0,96 não é nada, mesmo que não digam em alta e clara voz que 0,96 não é nada. Mas se você estiver com a sensação de que 0,96 não é nada, pode ser porque, dentro de você, o fenômeno inconsciente de desconfiança em relação às realizações teóricas dos brasileiros esteja pulsando e se fazendo sentir. Pode ser. Não dá para ter certeza. Mas é uma possibilidade. Como saber? É muito difícil. Eu não me atreveria a afirmar com certeza que a sua objeção contra 0,96 é um reflexo do seu preconceito epistêmico. Se eu entrasse no modo de ataque, você entraria no modo de defesa e a gente não chegaria a lugar nenhum. A possibilidade de acessar o 
fenômeno das preferências implícitas por meio da introspecção estaria perdida para sempre. Não adianta bater boca aqui. A melhor coisa a fazer é tirar o foco da questão por um momento. Será que você continuaria achando 0,96 um valor insignificante se descobrisse que perdeu uma bolsa de estudos ou uma vaga de emprego por causa de uma fração de ponto que a banca examinadora esqueceu de computar?

A gente pode pensar que 0,96 não é nada. Mas o fato de que consegui detectar um favorecimento de 0,96 não significa que, no mundo real, o favorecimento seja de apenas 0,96. Em primeiro lugar, porque existe muita diferença entre 0,96 e 0,96. Numa disciplina de graduação, 0,96 ponto pode não significar nada. Mas se você estiver concorrendo a uma bolsa de estudos ou uma vaga de emprego, a coisa pode ser decidida por causa de 0,5 ponto, até menos. Então não dá para olhar para o efeito de 0,96 e dizer de maneira peremptória que ele é um efeito pequeno e insignificante. Se a situação em questão não envolver muita concorrência, é claro que o efeito de 0,96 não vai contribuir muito para o resultado final. Mas se a concorrência for alta, um efeito menor, de 0,5 ponto, poderá ser decisivo.

Em segundo lugar, um instrumento de coleta de dados mais afiado poderia ter detectado um efeito maior, talvez de 1,5 ponto ou de 2,0 pontos. O resultado que obtive não consiste em um reflexo fiel e exato da realidade. Ele é também um reflexo da capacidade discriminatória do instrumento que utilizei na minha pesquisa. E não tenho dúvida nenhuma de que os questionários podem ser aprimorados. Agora eu entendo muito melhor o fenômeno das preferências implícitas do que entendia três anos atrás, quando desenvolvi, com a ajuda dos meus orientadores, o instrumento que usei no meu doutorado. Por exemplo, hoje eu faria um questionário com dois textos, no máximo. Não três. A vantagem de usar dois textos é que assim você consegue obter mais variáveis dependentes e combiná-las de maneiras diferentes. A desvantagem é que a atenção e o interesse do respondente tende a diminuir com a extensão do questionário - e assim você pode acabar com um resultado menos robusto. Sempre há perdas e ganhos. O que a gente precisa fazer é testar as alternativas que a gente tem em mãos para ver qual é a que dá melhores resultados, qual é a mais eficiente.

Agora também está muito mais clara para mim a importância de utilizar textos controversos, textos que podem ser ao mesmo tempo aplaudidos como originais e profundos, e rechaçados como absurdos e delirantes. Quanto mais controverso for um texto, maior será o seu poder de discriminação. Um brasileiro pode fazer um comentário muito competente sobre a obra de Spinoza. O que ele não pode fazer é ser original. Um grupo de biólogos fez uma pesquisa semelhante para ver se havia preconceito epistêmico de gênero na biologia. Só que eles usaram um texto completamente anódino, sem nada de ousado, completamente standard. E o que eles concluíram? Que não havia mais preconceito de gênero na biologia. Que ele tinha retrocedido com as novas gerações, muito mais acostumadas e abertas à participação das mulheres na ciência. Eu achei a conclusão meio apressada. Porque tudo o que se pode efetivamente concluir é que as biólogas não são discriminadas quando fazem pesquisas anódinas, pesquisas standard. Se você quiser ver se tem preconceito epistêmico na matemática, você não pode usar um texto que diz coisas triviais como $1+1=2$ ou $10+10=20$. Você tem que usar matemática de ponta. O que os sujeitos subepistêmicos não podem fazer é pesquisa de ponta. Não existe margem para você desconfiar da competência epistêmica das mulheres quando você usa um texto que fala coisas muito básicas sobre moluscos ou que fica no $1+1=2$ e $10+10=20$. Você tem que abrir espaço para o fenômeno das preferências implícitas vir à tona. Você tem que usar um texto capaz de acioná-las.

Eu achava que os professores brasileiros que se interessam pelo problema do colonialismo epistêmico - e eles são muito poucos - receberiam a pesquisa com entusiasmo, porque ela efetivamente fornece subsídios bastante fortes para afirmar que o problema que a gente tem no Brasil, ao contrário do que disse o Safatle, não é só institucional, não é só acadêmico. Ele é também um problema cognitivo. Ele atravessa a nossa pele e afeta o funcionamento dos nossos processos de raciocínio. Uma coisa é você criticar os departamentos de filosofia dizendo, como 
fazem Cabrera, Margutti, Porchat e Gonzalo, que neles se lê quase exclusivamente autores do norte atlântico. Outra coisa é você dizer que os membros dos departamentos de filosofia leem e avaliam os autores dos países periféricos e os autores dos países centrais de maneira diferente. No primeiro caso, é a função cultural e política da academia que está sendo colocada em questão. No segundo caso, é o nosso próprio aparelho cognitivo que está sendo colocado em questão. A coisa é muito mais radical e muito mais desestabilizadora. O que gente tem não é simplesmente um epistemicídio. É realmente um cognicídio.

Para a minha surpresa, porém, os professores que contatei para falar sobre a minha pesquisa reagiram com bastante frieza. Até mais do que com frieza. O que eu ouvi, como disse, foi coisas como "Todo mundo já sabia disso", o que é completamente absurdo. Se você pode desqualificar a minha pesquisa com um "Todo mundo já sabia disso", então você também pode desqualificar os trabalhos de Porchat, Gonzalo, Cabrera e Margutti com o mesmo argumento, e até com mais propriedade, porque as semelhanças entre o que eles fizeram são muito maiores, infinitamente maiores, do que as semelhanças entre o que eles fizeram e o que eu fiz. Eu percebi que não dava para convencer ninguém simplesmente dizendo "Os membros da comunidade brasileira de filosofia discriminam os pensadores brasileiros e latino-americanos", porque as pessoas invariavelmente respondiam "Não é uma questão de preconceito. Não lemos os brasileiros e latino-americanos porque aquilo que eles escrevem é de baixa qualidade". E como é que você responde ao argumento da qualidade? Pegando As Sutilezas do Mau-Caratismo, do Ézio Flávio Bazzo, e mostrando que ele não deixa nada a desejar em relação a Ecce Homo, do Nietzsche? Seria uma perda de tempo. Porque como As Sutilezas e o Ecce Homo são textos diferentes, não dá para afirmar que eles são idênticos em termos qualidade - e da diferença de qualidade para a superioridade de Nietzsche é só um passo. Então era preciso enfrentar o argumento da qualidade. Era preciso neutralizá-lo. E a única forma segura e convincente de neutralizá-lo era resolvendo o quebra-cabeças das diferenças inelimináveis. Eu vi que não dava para resolver a questão dentro do plano puramente discursivo. Era preciso incidir no plano discursivo de maneira ortogonal, com um dispositivo que permitisse decidir entre a tese de que os autores brasileiros e latino-americanos eram excluídos sem justificação (isto é, "Os membros da comunidade brasileira de filosofia discriminam os pensadores brasileiros e latino-americanos") e a tese de que eram excluídos de forma perfeitamente justificada (isto é, "Não lemos os brasileiros e latino-americanos porque aquilo que eles escrevem é de baixa qualidade"). Eu vi que não dava para avançar na discussão sem responder ao argumento da qualidade, porque ele está no centro de todo o problema. Mas se você parar para ler Porchat, Gonzalo, Cabrera e Margutti com cuidado, você vai ver que eles não sabem o que dizer diante do argumento da qualidade. Eles não conseguem respondê-lo. Por quê? Porque eles não são ousados o suficiente para desafiar os limites disciplinares da filosofia.

É simplesmente falso que "Todo mundo já sabia disso". Ninguém sabia de coisa nenhuma. Mas não foi apenas a relevância da minha pesquisa que foi colocada em questão. A minha metodologia também foi colocada em questão. Por exemplo, um professor disse que os meus dados não tinham validade por causa de dois problemas fundamentais. O primeiro era que eu não tinha usado um grupo de controle. O segundo era que que havia aplicado o questionário com o autor francês e o questionário com o autor brasileiro para populações diferentes. Como o grupo de pessoas que respondeu o questionário com o autor francês era diferente do grupo de pessoas que respondeu o questionário com o autor brasileiro, eu não podia compará-los. Eu não sei se você percebeu a incoerência do argumento. Porque se eu não posso comparar os dados obtidos com grupos diferentes de pessoas - se eu não posso comparar as respostas ao questionário com o autor francês com as respostas ao questionário com o autor brasileiro -, como é que a aplicação de um terceiro questionário para um terceiro grupo, o grupo de controle, iria resolver as coisas? É difícil não suspeitar que ele teria reagido de maneira muito diferente - e muito mais racional - se a pesquisa tivesse sido feita por alguém que, aos olhos dele, tivesse as credenciais adequadas. 
Eu também ouvi que desenhei os questionários de maneira tendenciosa, que eu era positivista, que eu tinha preconceito contra os europeus, que eu era nacionalista, tudo o que você pode imaginar. Até um parecerista de uma revista de estudos pós-coloniais, a Postcolonial Studies, se posicionou contra a publicação de um artigo que escrevi com o argumento de que o efeito de 0,96 era muito pequeno, insignificante. Como ele chegou na conclusão de que 0,96 era insignificante constitui um mistério. Ele disse também que, como a pesquisa dizia respeito à comunidade acadêmica brasileira de filosofia, o artigo deveria ter sido enviado para uma revista brasileira, não para a Postcolonial Studies. Achei a sugestão asquerosa. Até porque a Postcolonial Studies publica continuamente estudos claramente focados em nacionalidades específicas. Por exemplo, se você entrar no site deles agora, você vai encontrar, logo na primeira página, estudos que tematizam explicitamente países como Singapura, Timor Leste, Índia e Austrália. Então não tem nenhum sentido dizer que enviei o meu estudo para a revista errada. O problema da minha pesquisa obviamente foi outro. Qual? No começo do parecer, ele disse que o artigo tinha o mérito de transformar em hipótese e testar experimentalmente uma coisa que os teóricos do póscolonialismo simplesmente tomavam como pressuposto, a saber, que o eurocentrismo epistêmico afetava a nossa forma de avaliar as obras produzidas em diferentes partes do mundo. Então o artigo tinha, sim, algo de inovador. E aqui chegamos na raiz do problema. Os brasileiros podem escrever coisas medíocres, insípidas e anódinas. Eles podem fazer perfeitamente bem trabalhos convencionais, que só repetem a narrativa standard. O que eles não podem fazer é sair do lugar que lhes é atribuído na divisão internacional do trabalho intelectual. Se você olhar os artigos publicados na Postcolonial Studies, você vai ver que eles só repetem o mesmo discurso de sempre. Não há nada novo ali. Não há nada que valha a pena ser lido. Eu não me surpreenderia se uma auditoria descobrisse que a Postcolonial Studies discrimina de maneira regular os autores dos países periféricos, publicando apenas os seus trabalhos mais modestos e inexpressivos, e rejeitando sistematicamente os seus trabalhos mais interessantes e potencialmente inovadores. $\mathrm{O}$ jogo acadêmico não é tão limpo quanto parece.

Mas uma coisa precisa ser dita. Você disse que eu fiz algo que não havia sido feito ainda. Há controvérsias, você sabe. Eu ouvi repetidas vezes que a minha pesquisa não tinha nada de original. Talvez os meus críticos tenham razão. Talvez ela realmente não tenha nada de original. Ou talvez ela seja realmente original, até mais original do que parece. A questão é controversa. E acho que ela é controversa porque sou brasileiro. Se uma pesquisa semelhante tivesse sido feita por um francês, acho que a tendência seria vê-la como original, até como revolucionária. Mas eu sou brasileiro. Então o negócio fica meio complicado. A gente tem que lembrar que existe uma política da originalidade. Um filósofo francês que fizesse uso de pesquisas experimentais para trazer à tona preconceitos inconscientes estaria se rebelando contra os limites metodológicos da sua disciplina, transgredindo tabus epistêmicos, desafiando fronteiras acadêmicas, ampliando os horizontes do pensamento, renovando a filosofia - e, de quebra, dando uma força para a esquerda, chamando a sua atenção para um problema que ela não tinha visto antes e contribuindo para a luta contra as infinitas faces da injustiça. Mas eu, que sou brasileiro, estou sendo positivista. Estou sendo conservador. Estou cometendo erros metodológicos. Estou dizendo algo que todo mundo já sabia. É imperativo me colocar de volta no meu lugar. Mesmo que seja preciso lançar mão de argumentos completamente incoerentes, como o argumento de que não usei um grupo de controle ou o argumento de que enviei o meu artigo para a revista errada. A manutenção da geopolítica do saber é mais importante do que a manutenção da integridade intelectual.

Acho que aqui está a chave para entender a maior dificuldade enfrentada pela filosofia brasileira. Porque, se você parar para pensar, o nome do autor, que liga o seu trabalho com o Brasil, um país subalterno, e onde se fala uma língua subalterna, é só um signo entre outros. Quando comecei a minha pesquisa, eu achava que o problema era você ter um nome que entregava a sua nacionalidade, que mostrava que você era brasileiro. Eu não tinha percebido ainda que havia toda uma lexopolítica governando sutilmente, mas firmemente, o próprio ato de leitura. Quando 
você lê a palavra insight, os seus olhos seguem em frente, eles vão imediatamente para a próxima palavra, a leitura continua como se nada tivesse acontecido. A sua atenção não é desviada do significado do texto para os seus signos. Mas quando você lê a palavra "sacada", que tem o mesmo significado, a leitura dá uma travada, mesmo que uma travada sutil. A sua atenção é desviada do significado do texto para os seus signos. Por causa de uma simples palavra, toda a sua argumentação perde força e legitimidade. A mesma coisa pode ser dita sobre o Holocausto e a Chacina da Candelária. Quando você lê uma reflexão sobre a desumanização, a leitura não freia quando você encontra uma referência ao Holocausto. Ele não tem um efeito desagregador. Ele não tem um efeito corrosivo sobre a análise. Mas se você tivesse encontrado não uma referência ao Holocausto e sim à Chacina da Candelária, a leitura teria dado uma travada. A Chacina da Candelária é avessa ao saber, é avessa ao conhecimento. Ela é avessa à filosofia. Você não sente que o Holocausto foi um acontecimento espacialmente localizado, embora tenha sido, mas sente que a Chacina da Candelária foi espacialmente localizada, por mais que ela ultrapasse a si mesma para revelar algo importante sobre o caráter brutal do processo de modernização. Então esse é o problema. Se você não pode falar da realidade brasileira, você não pode fazer uma filosofia brasileira. Para você fazer uma filosofia em pretoguês, para você fazer uma filosofia que beba no pensamento ameríndio, para você fazer uma filosofia que use exemplos tomados do Brasil assim como Žižek toma continuamente exemplos tirados dos países comunistas e Foucault exemplos tirados da França -, você vai ter que saturar o seu texto de signos deslegitimadores e desagregadores. Então é realmente impossível, aos olhos dos brasileiros, fazer uma filosofia que tenha feições brasileiras. Não é logicamente impossível. Mas é subjetivamente impossível. É lexopoliticamente impossível. Como é que você vai construir algo implodindo continuamente o que você está fazendo? Toda vez que você usa um signo brasileiro, você está sinalizando que o que você está fazendo não é filosofia. Ou que é filosofia, só que de qualidade duvidosa.

Diante desse impasse, como fazer uma filosofia no Brasil que não seja meramente de espanador (usando uma ótima metáfora presente em seu livro)? Esse me parece um ponto chave, pois para o pensamento filosófico não basta o pensamento filosófico, é necessário que o mesmo seja reconhecido como tal pelo campo institucionalizado do saber. Como fazer isso nesse cenário de subordinação na geopolítica do conhecimento? Parece que não basta desvelar a realidade articulando reflexões e dados empíricos, como você bem fez, me parece que é um campo que precisa mais do que isso. O que você acha? Qual rumo sua filosofia deve seguir?

A gente tem que fazer aquilo que a gente não pode fazer. A gente tem que fazer aquilo que a gente acha que não tem capacidade de fazer - e que a gente efetivamente se proíbe de fazer. É curioso ver que a gente se proíbe de fazer aquilo que a gente acha que não tem capacidade de fazer, porque uma coisa coloca em questão a necessidade da outra. É como se você estivesse dizendo ao seu filho "Não atravesse a parede!" O lance é que se você realmente acha que ele é incapaz de atravessá-la, não há razão para proibi-lo de atravessá-la. Mas o que a gente tem bloqueando o desenvolvimento do pensamento no Brasil são as duas coisas, a proibição, que apesar de nunca ser abertamente declarada, é bastante firme e inflexível, e a crença na nossa incapacidade, que também vive nas sombras, só saindo de lá em caso de necessidade, e que é terrivelmente imobilizadora. O problema de acharmos que nós, brasileiros, somos incapazes de pensar, de que a originalidade é uma prerrogativa dos europeus (e agora cada vez mais também dos norte-americanos), não é só que a gente é levado a perguntar "Quem é você para achar que pode desenvolver uma teoria própria?" ou "Quem é você para criticar Foucault?" quando a gente vê alguém saindo do seu lugar, mas que a gente também é levado a perguntar "Mas quem sou eu para achar que posso desenvolver uma teoria própria?" ou "Quem sou eu para criticar Foucault?" quando a gente tem uma ideia que não condiz com a nossa posição subalterna na divisão internacional do trabalho intelectual. Não dirigimos nossas flechas apenas contra os nossos conterrâneos. Também as dirigimos contra nós mesmos. Então a gente tem um trabalho 
enorme pela frente. Nunca vamos conseguir pensar - não com toda a força e radicalidade que o pensamento exige - se não nos sentirmos no direito de pensar. A gente só vai até onde a gente sente que tem o direito de ir. Quando a gente tenta ir mais longe do que a gente sente que pode ir, o pensamento desacelera, emperra, turva, perde força e começa a se desagregar. E isso vale tanto para a nossa capacidade de avaliar seriamente quem está saindo do seu lugar para criticar Foucault quanto para a nossa capacidade de levar adiante as nossas intuições que conduzem a uma crítica de Foucault. Nos dois casos, o pensamento se desfaz no seu inverso. Ele precisa de energia para se mover. Ele precisa de energia para seguir em frente. Mas a energia o abandona quando ele ameaça quebrar as regras que delimitam o seu espaço de manobra.

Então o meu primeiro inimigo sou eu mesmo. Porque eu internalizei a mentalidade que me vê como - e que ativamente faz de mim - um agente epistêmico de segunda categoria. Ela não está só nos outros, ela também está em mim. Eu sinto que não posso ir muito longe. Eu sinto que preciso me moderar. Existe uma série de experimentos sobre um fenômeno chamado em inglês de stereotype threat - que poderíamos traduzir como ameaça estereotípica - que ilustram muito bem como a coisa funciona. Por causa do estereótipo de que os japoneses são gênios da matemática, se você colocar um matemático que não é japonês para fazer um teste de matemática - e ele tem que ser um teste difícil - numa sala cheia de japoneses, o desempenho dele será pior do que se você colocá-lo numa sala sem japoneses. $\mathrm{O}$ fato de que, no plano consciente, ele não acredita no mito da superioridade intelectual dos japoneses não significa nada. O desempenho dele será prejudicado da mesma forma. O interessante é que o desempenho dele só será afetado se o teste for suficientemente difícil para colocar os seus conhecimentos de matemática à prova. A coisa funciona exatamente como o preconceito inconsciente que temos contra a competência dos agentes epistêmicos subalternos. Se eles estiverem fazendo algo que se conforma ao que achamos que eles são capazes de fazer - se eles não estiverem saindo do seu lugar -, não será preciso puni-los, não será preciso admoestá-los. O preconceito só é exercitado em caso de necessidade. Só é preciso colocar de volta ao seu devido lugar quem sai dele. Da mesma forma, a ameaça estereotípica só entra em ação quando o nosso desempenho se aproxima perigosamente de um nível elevado demais para a nossa classe. Então temos aqui um obstáculo muito objetivo ao pensamento, um obstáculo que é inclusive mensurável - e estou falando aqui do pensamento não qua fenômeno público, interpessoal, e sim qua fenômeno interno, psicológico, intrapessoal. De maneira geral, os outros não precisam me policiar porque eu já policio a mim mesmo. Eu não me permito sair do meu lugar epistêmico. É claro que se eu conseguir superar minhas barreiras interiores, ainda vou ter um longo caminho pela frente. Mas a gente tem que lembrar que elas não são apenas exteriores. Elas estão dentro da gente. É como se houvesse uma espécie de mapa transcendental - e é ele que é o objeto central da oftalmologia - ao qual a realidade precisasse se conformar, um mapa extremamente elusivo, extremamente furtivo, mas também extremamente rígido, extremamente empedernido. Eu vejo a oftalmologia como uma geografia das estruturas transcendentais que organizam a nossa sociedade, como um estudo do espírito - que é muito mais perverso, muito mais demoníaco do que o espírito hegeliano - que modela tanto a nossa realidade externa quanto a nossa realidade interna. Os trilhos da história são fortes como os deuses. A gente pode pagar um preço alto por desafiá-los. Mas a gente precisa desafiá-los. Não temos muitas alternativas. Ou seguimos o rebanho ou nos rebelamos.

A dimensão interna e psicológica do pensamento é uma coisa séria. A figura de Foucault se tornou tão importante para a esquerda acadêmica que não seria um exagero dizer que ela ocupa em sua economia psíquica uma posição análoga à ocupada pela figura de Deus na economia psíquica dos cristãos. Os dois são símbolos fortemente catexizados, símbolos que dão sentido e amarram com fios invisíveis tudo ao seu redor. Para quem carrega Foucault na cabeça assim como os cristãos mais fervorosos carregam Deus no peito, é muito difícil - é psicologicamente difícil, é emocionalmente difícil - considerar a hipótese de que talvez tenha sido ele e não Marx que fez uma tempestade numa piscina de crianças. Assim como não se questiona a autoridade de Deus, não se questiona a autoridade de Foucault. Assim como quem questiona Deus tem 
necessariamente parte com o mal, quem questiona Foucault tem necessariamente parte com a direita. Se é assim que as coisas funcionam na sua cabeça, se a figura de Foucault está simbolicamente blindada, você nunca vai conseguir, por exemplo, analisar seriamente as críticas dele ao conceito de ideologia para ver se elas procedem. Quando você começar a achá-las estranhas, quando você começar a achá-las fracas, o seu pensamento vai emperrar e ficar confuso - e você vai recuar. E quanto ao conceito de poder? Quem tem coragem de criticá-lo? Quem tem coragem de desafiar a sua importância? Quem tem coragem de dizer que combatê-lo é combater o inimigo errado? Quem tem coragem de dizer que é perfeitamente possível elaborar um pensamento robusto e afiado de esquerda sem usá-lo? A coisa está fora de cogitação. A luta contra o poder se tornou um axioma do pós-estruturalismo. Ele é parte essencial de sua metanarrativa. Apesar de todo seu antidicotomitês, o poder é o mal por excelência. E quanto à hipótese de que o sucesso acadêmico dele talvez não seja um reflexo da sua relevância teórica, mas um reflexo do seu alinhamento ideológico com Washington, bem como da sua importância estratégica, como escritor relativamente prolífico, e de leitura relativamente árdua, que demanda tempo e energia para ser digerido, na luta contra o ideal de igualdade econômica? Nem pensar. É possível que a crítica de Foucault ao conceito de ideologia seja uma furada. É possível que o seu conceito de poder não seja tão revolucionário quanto parece. É possível que o sucesso dele se deva ao fato de que ele estava criticando o marxismo numa época em que havia forças extremamente poderosas trabalhando para deslegitimá-lo. Mas se a gente não conseguir se emancipar - e se emancipar psicologicamente - do apelo simbólico da figura de Foucault, a gente nunca vai conseguir criticá-lo. Se a gente não conseguir se emancipar da geopolítica do saber, a gente nunca vai conseguir filosofar.

E o que eu estou fazendo? Quais são os rumos que os meus pensamentos estão tomando? Eu estou sempre tentando fazer o que sou proibido de fazer - e o que proíbo a mim mesmo de fazer. Não posso fazer pesquisas empíricas? Estou fazendo pesquisas empíricas. Não posso criticar Foucault? Estou criticando Foucault. Não posso lê-lo a não ser segundo os princípios do método estrutural de leitura? Estou lendo Foucault contra o pano de fundo da Guerra Fria. Não posso trabalhar nas minhas sacadas? Não posso desdobrá-las para ver onde elas levam? Pois não tenho as credenciais necessárias? Pois elas são - basta ver a minha nacionalidade! - ideias fracas, anêmicas e rasas? Pois sou por definição intelectualmente incapaz de desenvolvê-las da forma adequada? O lado bom de carregar o peso de tantas proibições nas costas é que assim posso ver claramente por onde seguir. $\mathrm{O}$ que eu tenho que fazer é precisamente aquilo que não posso fazer. $\mathrm{O}$ que eu tenho que fazer é precisamente aquilo que sou incapaz de fazer. E o que não posso fazer em hipótese alguma é precisamente aquilo que é da minha alçada e está ao meu alcance. O que não posso fazer em hipótese alguma é a única coisa que sou capaz de fazer, que é comentar, desempoeirar os clássicos, levantar a bandeira de uma das correntes dominantes da filosofia acadêmica contemporânea - seja ela a filosofia analítica, a fenomenologia ou o pósestruturalismo. Se tenho alguma obrigação, não é a obrigação de me alinhar a elas, mas a obrigação de me desvencilhar delas. Até porque elas já estão mais do que ultrapassadas - não no sentido de que elas não chegaram no século XXI, mas no sentido de que chegaram ofegantes, quase mortas. Não dá mais para negar suas limitações, que não são nada desprezíveis.

Gostaria de retomar o tema da conjuntura. Nesse momento de antevéspera de um governo no Brasil abertamente autoritário, ultraliberal na economia e conservador nos costumes, qual é o papel da filosofia?

O papel da filosofia? Infelizmente, a filosofia sofre de um sério problema. Ela é extremamente conservadora do ponto de vista temático e metodológico, muito mais do que as demais disciplinas de humanas - que, aliás, também têm seus conservadorismos. Não é que ela tenha uma cartilha conservadora. $\mathrm{Na}$ verdade, a cartilha dela é até interessante. A filosofia se apresenta como extremamente revolucionária, como incomparavelmente revolucionária. Como é que geralmente se define a filosofia? Como uma atividade implacavelmente, até mesmo 
irritantemente questionadora. Qual é o seu inimigo número um? O senso comum, o óbvio, o evidente em si mesmo. A sua especialidade é andar na contramão das certezas. O que todo mundo toma como pressuposto, a filosofia toma como objeto de estudo. Então como uma atividade tão radicalmente questionadora, que se define em oposição ao óbvio, e que, pelo menos em teoria, pensa de forma livre de pressupostos, sempre dirigindo contra eles a sua fúria, pode ser conservadora? $\mathrm{O}$ fato é que a filosofia não é tão livre de pressupostos quanto ela pensa. Existem muitas coisas que ela não questiona. Evidentemente, ninguém tem a obrigação de questionar tudo. Mas existem muitas coisas que ela não questiona não por serem coisas de pouca importância e sim apesar de serem coisas de extrema importância. Por exemplo, você vê a filosofia discutindo as mídias sociais? Não. Por quê? Porque, do ponto de vista da filosofia, tratase de um assunto frívolo, superficial, sem peso e sem importância. Não é que a discussão das mídias sociais esteja explicitamente vedada pela filosofia. Mas ela está vedada de maneira subentendida, de maneira implícita. Você pode falar sobre as mídias sociais numa conversa de bar. Mas se você não quiser correr o risco de ver sua reputação intelectual colocada em questão, é melhor você se ater, dentro da academia, aos temas autorizados, aos temas bem-comportados, aos temas, digamos assim, intraparadigmáticos, como, por exemplo, o que Hegel entendia por Espírito, o que Nietzsche entendia por Übermensch e o que Wittgenstein entendia por Sprachspiel. Se você fala de Sprachspielen, você ganha prestígio. Se você fala de mídias sociais, você perde prestígio. Se você fala de Sprachspielen, você se insere firmemente no espaço discursivo da filosofia e afirma a sua competência epistêmica. Se você fala de mídias sociais, você sai do espaço discursivo da filosofia e alardeia a sua incompetência epistêmica. A propriedade do que você fala sobre Sprachspielen pode ser questionada, mas não a propriedade de se falar sobre Sprachspielen. Com as mídias sociais acontece o contrário. $\mathrm{O}$ fato de que é inapropriado falar delas faz com que seja totalmente irrelevante se o que você está falando é apropriado ou não. Pois você está contaminando a filosofia com uma conversa de bar. Você está contaminando o mundo das ideias com o mundo empírico. Então a filosofia - e estou falando aqui da filosofia acadêmica - não é tematicamente neutra. Ela traça uma fronteira bastante nítida entre o que pode e o que não pode ser tematizado, entre o que pode e o que não pode ser discutido. $O$ que caracteriza a filosofia não é apenas como ela olha para as coisas, mas também as coisas para as quais ela olha. $\mathrm{E}$ isso significa que ela desvia o olhar de muitas coisas - por medo de perder sua elegância, por medo de se descaracterizar, por medo de deixar de ser filosofia. E o que acontece é que assim ela perde seu poder contestador, perde sua força política - e, num sentido importante, deixa de ser filosofia.

Mas o tema das mídias sociais é um tema importante? É um tema que deveria ser discutido? Sim, sem dúvida. Em primeiro, porque as mídias sociais têm hoje a importância que a televisão tinha até pouco tempo atrás, e que as rádios tinham antes da televisão. Em segundo, e isso é o mais importante, porque elas estão sendo usadas cada vez mais para fins militares - e cada vez com mais eficiência. Durante a Guerra Fria, os Estados Unidos e a Inglaterra transformaram livros em armas. Agora eles deram um jeito de fazer a mesma coisa com as mídias sociais. O sucesso da campanha de Trump provou de uma vez por todas que elas podem, sim, ser usadas para manipular o comportamento de populações inteiras. Eu acho, inclusive, que a eleição de Trump foi a prova de fogo que mostrou, para além de qualquer dúvida possível, que a arma de guerra desenvolvida pela Cambridge Analytica - a empresa que coordenou a sua campanha - realmente funciona. A hipótese de que a eleição de Trump foi uma espécie de pitching não é totalmente implausível. Se você faz um palhaço como o Trump ganhar a corrida presidencial - e ganhá-la por apenas 70 mil votos estrategicamente localizados, contra uma candidata que, no total, recebeu quase 3 milhões de votos a mais -, é porque você realmente tem uma ferramenta muito poderosa em mãos, uma ferramenta que não pode ser ignorada. Então o que aconteceu no Brasil foi muito bem planejado. A ferramenta já havia sido testada. Não havia dúvida nenhuma sobre sua eficiência. O que colocou o Bolsonaro no poder não foram os erros do Partido dos Trabalhadores nem os acertos do Partido Social Liberal. O que colocou o Bolsonaro no poder 
foi uma das armas de guerra mais sofisticadas já desenvolvidas até hoje, de custo operacional baixíssimo e de resultados praticamente garantidos. Então você não vai conseguir entender muita coisa sobre o mundo contemporâneo se você não incluir as mídias sociais entre os seus objetos de estudo. Você pode achar - e mais do que achar, você pode sentir - que falar delas é frívolo. Você pode achar - você pode sentir - que é melhor deixá-las no silentio regnum, pois elas apequenam intelectualmente quem as tematiza. Mas dada a extrema importância das mídias sociais para os desenvolvimentos políticos que estamos vendo atualmente, está na hora de deixarmos nossos pudores disciplinares de lado. Não é o tema das mídias sociais que é frívolo. Não é o tema das mídias sociais que é superficial. É o olhar da filosofia - o olhar da filosofia acadêmica - que precisa ser atualizado.

O Brasil é hoje uma nação ocupada. Ter o Bolsonaro como presidente é como ter um general estrangeiro como presidente. É exatamente a mesma coisa. Mas com uma diferença importante: é muito pior. Porque o Bolsonaro, tendo nascido em território nacional, sendo falante do português - embora seja um português só de fachada, porque, não dá para negar, a língua que ele fala mesmo é o inglês -, possui todas as características de um presidente legítimo. Afinal, ele não foi eleito? Ele já não estava na carreira política? Ele não foi deputado por 27 anos? Ele não é brasileiro? É aí que está o problema. Porque se o Brasil tivesse sofrido uma ocupação tradicional, estaríamos resistindo com todas as forças. Estaríamos jogando pedras contra tanques de guerra, fazendo buscas na internet para aprender a fabricar bombas caseiras, estudando o manual de guerrilha urbana do Carlos Marighella. Só que o Bolsonaro, sendo brasileiro, e tendo o apoio de uma parcela não desprezível da população, confere à ocupação estrangeira um ar de legitimidade. O que você prefere? Gastar bilhões de dólares para invadir um país, manchando a sua imagem junto à comunidade internacional e despertando a ira da população local - ira que poderá se prolongar por duas ou três gerações, representando, como os Estados Unidos e a Inglaterra hoje sabem muito bem, um risco, ainda que mínimo, para a sua segurança nacional? Ou limitar seus gastos a não mais que 10 milhões de dólares e conseguir tudo o que você quer com o apoio da população local e sem o dedo em riste da comunidade internacional? A gente tem que parar de achar que as eleições de 2018 foram atípicas só porque vamos ter agora um reacionário incompetente como presidente. Elas foram atípicas porque elas consistiram em um ataque descarado à soberania nacional. Não foi uma simples operação de marketing que colocou o Bolsonaro no poder. Foi uma operação de guerra. Mas uma operação de guerra ultramoderna, muito bem planejada e muito bem executada. O que a gente está vendo é uma reedição de 1964 não só no sentido de que vamos ter um governo militar - ou um governo que pelo menos carrega abertamente uma áurea militar -, mas também no sentido de que vamos ter um governo arquitetado no exterior. E o Bolsonaro já deixou muito claro que o seu governo não vai ser só repressivo. Ele vai ser também, e sobretudo, um governo entreguista.

É uma pena o fato de que os intelectuais brasileiros não têm a mínima ideia do que está acontecendo. Se você achava que a metafísica era um conjunto de proposições sem sentido, você ainda não viu nada. A coisa vai ficar muito feia. E os intelectuais estão interpretando tudo como se fosse o resultado de forças políticas internas. Trata-se de um erro grosseiro - que também foi cometido, e ainda se comete, em relação a 1964. O problema é que as coisas estão claras como a luz do dia. A empresa que coordenou a campanha do Bolsonaro, a Cambridge Analytica - que mudou seu nome para Emerdata, a fim de desviar a atenção dos críticos -, nunca foi uma simples empresa de marketing. Você já viu uma empresa de marketing escolher seus clientes a dedo? E o que é ainda mais paradoxal, escolher precisamente os clientes com menos recursos financeiros? Apesar de seu histórico de transações suspeitas, o fato é que a família Bolsonaro, que antes da corrida presidencial quase ninguém conhecia, não tinha condição alguma de contratar a empresa que colocou Trump na presidência dos Estados Unidos. A gente está falando da empresa de marketing mais bem-sucedida do mundo trabalhando de graça para um político sem nenhuma visibilidade que não tem a menor possibilidade de pagar por seus serviços. O interesse da Cambridge Analytica pelo Bolsonaro não pode ter sido econômico. É como se o 
Royce Gracie tivesse desistido de treinar as forças armadas dos Estados Unidos para treinar os seguranças do Carrefour achando que assim ganharia mais dinheiro. A conta não bate. Até porque a Cambridge Analytica nunca teve vocação filantrópica. Então se ela fosse realmente uma empresa de marketing - e uma empresa de marketing como todas as outras, que têm como meta principal lucrar -, ela teria oferecido seus serviços, sei lá, ao Ciro Gomes, não ao Bolsonaro, que não tinha nada na cabeça e muito pouco no bolso. A história está muito mal contada.

E para piorar as coisas, a filosofia acadêmica, que já não era muito crítica - pelo menos, não suficientemente crítica para lidar com nossos problemas -, está agora completamente amordaçada. Ela já tinha excluído o Brasil do seu universo de discurso. Agora é o Brasil que ameaça excluí-la do seu território. Já tínhamos uma filosofia sem o Brasil. Agora corremos o risco de ter um Brasil sem filosofia. E sem qualquer forma de pensamento crítico, na verdade. A qualidade do ensino no Brasil sofreu um ataque brutal durante a ditadura - em todos os níveis, não só no universitário. A mesma coisa está prestes a se repetir - e de novo em todos os níveis, mas principalmente no universitário. O pensamento já está intimidado. Os professores já estão com medo de se expressarem livremente em sala de aula - com medo de serem processados, de serem demitidos, até de serem agredidos. E os seus medos estão plenamente justificados. A coisa pode ficar muito feia. Não se trata de paranoia, você sabe. A antropóloga Débora Diniz, por exemplo, decidiu sair do país por causa das ameaças de morte que sofreu. Então o clima de medo já está instalado. E se o pensamento se rebelar? E se ele contra-atacar? E se ele não aceitar se calar? Eu não me surpreenderia se acontecesse no Brasil algo como o que aconteceu quando os Estados Unidos invadiram o Iraque em 2003, com a desculpa - que todo mundo sabia ser esfarrapada, até mesmo os americanos - de que Saddam Hussein tinha armas de destruição em massa. A estimativa é que em pouco mais de um ano, cerca de 200 dos mais importantes pesquisadores e intelectuais iraquianos - a maioria de humanidades - já tinham sido mortos. Ou o que aconteceu foi uma terrível coincidência que desafia todas as leis da estatística ou temos que levar a sério a hipótese de que eles foram sistematicamente assassinados. Mas talvez não seja preciso fazer a mesma carnificina no Brasil. Os intelectuais iraquianos não tinham ilusões a respeito dos Estados Unidos. Não dá para dizer o mesmo sobre os intelectuais brasileiros. O que não quer dizer que eles podem dormir tranquilos. Porque perambulando pelo Brasil existem agora milhares e milhares - ou melhor, milhões e milhões - de zumbis colocados em circulação pela Cambridge Analytica. 